\title{
Two dimensional intraoperative transesophageal echocardiography (TEE) allows length-calculation of neo-chordae for mitral valve repair
}

\author{
MH Ammar*, A Zandi, H Ebel, H Bigdeli, M Roosta-Azad, M Kamler \\ From 23rd World Congress of the World Society of Cardio-Thoracic Surgeons \\ Split, Croatia. 12-15 September 2013
}

\section{Background}

The loop technique for mitral valve repair is complicated by accurate estimation of length of neo-chordae in the arrested heart. It was the aim of the study to evaluate the value and accuracy of perioperative dynamic TEE to assess the adequate length of artificial choradae in comparison with the surgeon's in situ measurements.

\section{Methods}

From July 2010 to April 2013, 95 consecutive patients (mean age, $63 \pm 20$ years, mean LVEF, $50 \% \pm 15 \%$ ), with severe mitral valve regurgitation (ischemic $17 \%$. PML-prolapse $7.3 \%$. AML- prolapse 2, 1\%. PML and AML-Prolaps $6.3 \%$. Endocarditis $2.1 \%$. Barlow 1\%. Cleft with $\mathrm{AML}_{+}$ PML Prolapse 11,5\%. AML. Descaling 5, 2\%.) underwent mitral valve repair. Anticipated length of loops was assessed with TEE or with a custom made caliper (Geister Medizintechnik) by measuring the distance between the top of papillary muscle and the cooptation zone of intact leaflets in the end systolic phase or in the arrested heart.

\section{Results}

Overall 30 day hospital mortality was $0 \%$. Stroke rate was $0 \%$. Respiratory failure rate was $2 \%$. Freedom from reoperation rate was $99 \%$ (one Patient sever MR, ruptured papillary muscle). Follow up Echocardiography showed MR: $0-\mathrm{I}^{\circ}$ in $98 \%, \mathrm{I}^{\circ}-\mathrm{II}^{\circ}$ in $1 \%$ and $\mathrm{II}^{\circ}-\mathrm{III}^{\circ}$ in $1 \%$ of patients. Proposed length of neochordae by TEE was $22.1 \pm 3 \mathrm{~mm}$, length used by the surgeon was $21.2 \pm 3 \mathrm{~mm}$.

\section{Conclusions}

For optimization of the length of neo-chordae TEE is a valuable tool to help the surgeon to estimate the correct

\footnotetext{
* Correspondence: ammar_68@hotmail.com
}

Cardiac Surgery, Heart Center, Essen, Germany length in the arrested heart. Discrepancies are due to methological differences between the two methods and TEE values have to be judged by the surgeon in accordance to the local finding in the heart.

Published: 11 September 2013

doi:10.1186/1749-8090-8-S1-0270

Cite this article as: Ammar et al:: Two dimensional intraoperative transesophageal echocardiography (TEE) allows length-calculation of neo-chordae for mitral valve repair. Journal of Cardiothoracic Surgery 2013 8(Suppl 1):0270.
Submit your next manuscript to BioMed Central and take full advantage of:

- Convenient online submission

- Thorough peer review

- No space constraints or color figure charges

- Immediate publication on acceptance

- Inclusion in PubMed, CAS, Scopus and Google Scholar

- Research which is freely available for redistribution
() Biomed Central 